\title{
Genomics update
}

\section{The quest for biofuels fuels genome sequencing} OnlineOpen: This article is available free online at www.blackwell-synergy.com

\author{
Michael Y. Galperin* \\ National Center for Biotechnology Information, National \\ Library of Medicine, National Institutes of Health, \\ Bethesda, MD 20894, USA.
}

The list of recently completed microbial genome projects (Table 1) shows further progress in sequencing genomes of poorly studied environmental bacteria. The genome of Aquifex aeolicus, sequenced 10 years ago, has been joined by genomes of two more representatives of the phylum Aquificae. The genome of Polaribacter sp. MED152, a marine member of Bacteroidetes, revealed a combination of heterotrophic metabolism with light energy capture by proteorhodopsin. In addition, six genomes from the phylum Chlorobi more than doubled the number of sequenced genomes of green sulfur bacteria.

In eukaryotic genomics, important news was the release by the JGI scientists of a draft genome of the soft-rot ascomycete fungus Trichoderma reesei, also known as Hypocrea jecorina (Martinez et al., 2008). Trichoderma reesei is filamentous fungus that is widely used in biotechnology as a producer of various cellulases and hemicellulases for the hydrolysis of plant cell walls. This organism has attracted renewed interest owing to its potential use in the conversion of lignocelluloses to biofuel. The GenBank version of the draft genome of T. reesei consists of 2236 contigs, assembled into 170 scaffolds and containing $\sim 34 \mathrm{Mbp}$ of DNA, representing $\sim 99 \%$ of the whole genome. The current assembly did not assign the scaffolds to any of the seven chromosomes of $T$. reesei, but allowed identification of 9129 predicted protein-coding genes (Martinez et al., 2008). Comparison of T. reesei with Fusarium graminearum (Gibberella zeae) and Neurospora crassa revealed a certain degree of synteny between these three genomes. A surprising finding was the relatively low number of glycoside hydrolases (cellulases, hemicellulases and pectinases) encoded by T. reesei genome. The authors suggest that successful utilization by $T$. reesei of its limited set of

\footnotetext{
*For correspondence. E-mail galperin @ ncbi.nlm.nih.gov; Tel. (+1) 301 435 5910; Fax (+1) 3014357793.

Re-use of this article is permitted in accordance with the Creative Commons Deed, Attribution 2.5, which does not permit commercial exploitation.
}

cellulolytic enzymes to efficiently degrade plant cell walls could be due to (i) clustering of the respective genes that ensures co-expression of the right combination of hydrolytic enzymes, and (ii) secretion of secondary metabolites (Martinez et al., 2008).

Although phylogenetically unrelated to $T$. reesei, the $\gamma$-proteobacterium Cellvibrio japonicus also encodes an efficient machinery for degrading plant cell walls that includes 130 predicted glycoside hydrolases (DeBoy et al., 2008).

The current list includes two actinobacterial genomes, representing the soil bacterium Kocuria rhizophila (Takarada et al., 2008) and a new strain of the human gut symbiont Bifidobacterium longum (Lee and O'Sullivan, 2006; Lee et al., 2008). The genus Kocuria belongs to the family Micrococcineae and was separated from Micrococcus just a few years ago (Stackebrandt et al., 1995). Accordingly, K. rhizophila ATCC 9341, parental strain of the sequenced K. rhizophila DC2201, was until recently classified as Micrococcus luteus and used as a standard quality control strain in a number of applications, including testing of antimicrobial compounds (Tang and Gillevet, 2003). The genus name was assigned to honour Miroslav Kocur, Slovakian microbiologist who dedicated many years to studying M. luteus (Rosypal and Kocur, 1963; Kocur, 1986). Kocuria rhizophila is an environmental actinomycete that is often associated with plant roots. Despite its small (for a soil actinomycete) $2.7 \mathrm{Mbp}$ genome, K. rhizophila appears to encode the full set of key metabolic enzymes. However, it encodes fewer proteins participating in secondary metabolism, including single genes for a non-ribosomal peptide synthetase and a polyketide synthase. The relatively high tolerance of $K$. rhizophila to various organic compounds correlates with the presence of a large number of genes encoding various membrane transporters, including drug efflux pumps (Takarada et al., 2008).

The two newly sequenced genomes of Aquificae represent two major families in this phylum. Hydrogenobaculum sp. YO4AAS1 belongs to the family Aquificaceae, which also includes $A$. aeolicus, the best-characterized member of the phylum, whereas Sulfurihydrogenibium sp. YO3AOP1 belongs to the family Hydrogenothermaceae. Both are thermophilic chemolitoautotrophs, isolated from 
Table 1. Recently completed microbial genomes (May-July 2008).

\begin{tabular}{|c|c|c|c|c|c|c|}
\hline Species name & Taxonomy & $\begin{array}{l}\text { GenBank } \\
\text { accession }\end{array}$ & $\begin{array}{l}\text { Genome } \\
\text { size (bp) }\end{array}$ & $\begin{array}{l}\text { Proteins } \\
\text { (total) }\end{array}$ & $\begin{array}{l}\text { Sequencing } \\
\text { centre }^{\mathrm{a}}\end{array}$ & Reference \\
\hline \multicolumn{7}{|l|}{ New organisms } \\
\hline Trichoderma reesei & Eukaryota, Fungi & AAIL00000000 & $\sim 34 \mathrm{Mbp}$ & 9129 & JGI & Martinez et al. (2008) \\
\hline Kocuria rhizophila & Actinobacteria & AP009152 & 2697540 & 2357 & NITE & Takarada et al. (2008) \\
\hline Hydrogenobaculum sp. Y04AAS1 & Aquificae & СР001130 & 1559514 & 1629 & JGI & Unpublished \\
\hline Sulfurihydrogenibium sp. YOЗAOP1 & Aquificae & СР001080 & 1838442 & 1721 & JGI & Unpublished \\
\hline Candidatus Amoebophilus asiaticus & Bacteroidetes & CP001102 & 1884364 & 1283 & JGI & Unpublished \\
\hline Polaribacter sp. MED152 & Bacteroidetes & NZ_AANA00000000 & 2967150 & 2646 & JCVI & González et al. (2008) \\
\hline Chlorobaculum parvum & Chlorobi & CP001099 & 2289249 & 2043 & JGI & Unpublished \\
\hline Chlorobium limicola & Chlorobi & СР001097 & 2763181 & 2434 & JGI & Unpublished \\
\hline Chloroherpeton thalassium & Chlorobi & СР001100 & 3293456 & 2710 & JGI & Unpublished \\
\hline Pelodictyon phaeoclathratiforme & Chlorobi & СР001110 & 3018238 & 2707 & JGI & Unpublished \\
\hline \multirow[t]{2}{*}{ Prosthecochloris aestuarii } & Chlorobi & СР001108 & 2512923 & 2327 & JGI & Unpublished \\
\hline & & СР001109 & 66772 & & & \\
\hline \multirow[t]{3}{*}{ Natranaerobius thermophilus } & Firmicutes & СР001034 & 3165557 & 2906 & JGI & Unpublished \\
\hline & & СР001035 & 17207 & & & \\
\hline & & СР001036 & 8689 & & & \\
\hline \multirow[t]{3}{*}{ Methylobacterium populi } & $\alpha$-Proteobacteria & СР001029 & 5800441 & 5365 & JGI & Unpublished \\
\hline & & СР001030 & 25164 & & & \\
\hline & & СР001031 & 23392 & & & \\
\hline Oligotropha carboxidovorans & $\alpha$-Proteobacteria & ABKN00000000 & 3745772 & 3754 & Mississippi State U. & Paul et al. (2008) \\
\hline Wolbachia pipientis & $\alpha$-Proteobacteria & AM999887 & 1482455 & 1275 & Sanger Institute & Klasson et al. (2008) \\
\hline \multirow[t]{3}{*}{ Ralstonia pickettii } & $\beta$-Proteobacteria & СР001068 & З 942557 & 4952 & JGI & Unpublished \\
\hline & & СР001069 & 1302238 & & & \\
\hline & & СР001070 & 80934 & & & \\
\hline Cellvibrio japonicus & $\gamma$-Proteobacteria & СР000934 & 4576573 & 3754 & JCVI & DeBoy et al. (2008) \\
\hline \multirow[t]{2}{*}{ Erwinia tasmaniensis } & $\gamma$-Proteobacteria & CU468128 & 4.07 (total) & 3622 & MPIMG & Kube et al. (2008) \\
\hline & & CU468130-CU468135 & & & & \\
\hline \multirow[t]{2}{*}{ Proteus mirabilis } & $\gamma$-Proteobacteria & AM942759 & 4063606 & 3685 & Sanger Institute & Pearson et al. (2008) \\
\hline & & AM942760 & 36289 & & & \\
\hline \multirow[t]{2}{*}{ Geobacter lovleyi } & $\delta$-Proteobacteria & СР001089 & 3917761 & 3476 & JGI & Unpublished \\
\hline & & СР001090 & 77113 & & & \\
\hline Candidatus Phytoplasma mali & Tenericutes & CU469464 & 601943 & 479 & MPIMG & Kube et al. (2008) \\
\hline Mycoplasma arthritidis & Tenericutes & СР001047 & 820453 & 631 & JCVI & Dybvig et al. (2008) \\
\hline \multicolumn{7}{|l|}{ New strains } \\
\hline \multirow[t]{3}{*}{ Bifidobacterium longum DJO10A } & Actinobacteria & CP000605 & 2375792 & 2003 & JGI & Lee et al. (2008) \\
\hline & & AF538868 & 10073 & & & \\
\hline & & AF538869 & 3661 & & & \\
\hline Chlorobium phaeobacteroides BS1 & Chlorobi & СР001101 & 2736403 & 2469 & JGI & Unpublished \\
\hline Lactobacillus casei BL23 & Firmicutes & FM177140 & 3079196 & 3044 & INRA & Unpublished \\
\hline Streptococcus pneumoniae G54 & Firmicutes & СР001015 & 2078953 & 2115 & JCVI & Dopazo et al. (2001) \\
\hline Rhizobium etli CIAT 652 & $\alpha$-Proteobacteria & СР001074-СР001077 & 6.44 (total) & 6056 & UNAM & Unpublished \\
\hline Rhodopseudomonas palustris TIE-1 & $\alpha$-Proteobacteria & СР001096 & 5744041 & 5246 & JGI & Unpublished \\
\hline Burkholderia cenocepacia J2315 & $\beta$-Proteobacteria & AM747720-AM747723 & 8.05 (total) & & Sanger Institute & Unpublished \\
\hline Burkholderia multivorans ATCC 17616 & $\beta$-Proteobacteria & AP009385-AP009388 & 6.99 (total) & 6112 & Tohoku U. & Unpublished \\
\hline \multirow[t]{2}{*}{ Neisseria gonorrhoeae NCCP11945 } & $\beta$-Proteobacteria & СР001050 & 2232025 & 2674 & Korea NIH & Chung et al. (2008) \\
\hline & & СР001051 & 4153 & & & \\
\hline $\begin{array}{l}\text { Actinobacillus pleuropneumoniae } \\
\text { serovar } 7 \text { str. AP76 }\end{array}$ & $\gamma$-Proteobacteria & СР001091-СР001094 & 2.34 (total) & 2142 & Bielefeld U. & Unpublished \\
\hline \multirow{3}{*}{$\begin{array}{l}\text { Salmonella enterica subsp. enterica } \\
\text { serovar Heidelberg str. SL476 }\end{array}$} & $\gamma$-Proteobacteria & CP001120 & 4888768 & 4779 & JCVI & Unpublished \\
\hline & & СР001118 & 91374 & & & \\
\hline & & CP001119 & 3373 & & & \\
\hline \multirow{3}{*}{$\begin{array}{l}\text { Salmonella enterica subsp. enterica } \\
\text { serovar Newport str. SL254 }\end{array}$} & $\gamma$-Proteobacteria & СР001113 & 4827641 & 4805 & JCVI & Unpublished \\
\hline & & СР000604 & 176473 & & & \\
\hline & & CP001112 & 3605 & & & \\
\hline Salmonella enterica subsp. enterica serovar & $\gamma$-Proteobacteria & СР001127 & 4709075 & 4627 & JCVI & Unpublished \\
\hline \multirow[t]{2}{*}{ Schwarzengrund str. CVM19633 } & & СР001125 & 110227 & & & \\
\hline & & CP001126 & 4585 & & & \\
\hline Stenotrophomonas maltophilia R551-3 & $\gamma$-Proteobacteria & CP001111 & 4573969 & 4039 & JGI & Unpublished \\
\hline $\begin{array}{l}\text { Treponema pallidum subsp. } \\
\text { pallidum } \mathrm{SS} 14\end{array}$ & Spirochaetes & СР000805 & 1139457 & 1028 & Baylor & Matejkova et al. (2008) \\
\hline
\end{tabular}

Sequencing centre names are abbreviated as follows: Baylor, Human Genome Sequencing Center, Baylor College of Medicine, Houston, Texas, USA; Bielefeld U., Centrum für Biotechnologie, Universität Bielefeld, Bielefeld, Germany; INRA, Institut National de la Recherche Agronomique, Domaine de Vilvert, Jouy en Josas, France; JCVI, J. Craig Venter Institute, Rockville, Maryland, USA; JGI, US Department of Energy Joint Genome Institute, Walnut Creek, California, USA; Korea NIH, Center for Infectious Disease and Research, Korea National Institute of Health, Seoul, Korea; Mississippi State U., Mississippi State University, Mississippi State, Mississippi, USA; MPIMG, Max-Planck-Institute for Molecular Genetics, Berlin, Germany; NITE, Genome Analysis Center, Department of Biotechnology, National Institute of Technology and Evaluation, Shibuya-ku, Tokyo, Japan; Sanger Institute, The Wellcome Trust Sanger Institute, Wellcome Trust Genome Campus, Hinxton, Cambridgeshire, UK: Tohoku U., Department of Environmental Life Sciences, Graduate School of Life Sciences, Sendai, Miyagi, Japan; UNAM, Centro de Ciencias Genomicas, Universidad Nacional Autonoma de Mexico, Cuernavaca, Mexico. 
hot springs at Yellowstone National Park at $60-75^{\circ} \mathrm{C}$ and capable of growing in microaerophilic conditions by using reduced sulfur compounds and/or hydrogen as electron acceptors and $\mathrm{CO}_{2}$ as the source of carbon (Stöhr et al., 2001; Reysenbach et al., 2005). However, the former is an acidophile, growing at or below $\mathrm{pH} 3.0$, and the latter grows at neutral $\mathrm{pH}$ values. The genome size of Hydrogenobaculum sp. YO4AAS1 is very close to that of A. aeolicus, whereas Sulfurihydrogenibium sp. YO3AOP1 features a $300 \mathrm{~kb}$ larger genome and almost a hundred of extra proteins. Availability of these new genomes should provide a much-needed insight into the physiology of Aquificae, one of the earliest-branching bacterial lineages.

Of the two members of the highly diverse phylum Bacteroidetes in the current list, the first one, Candidatus Amoebophilus asiaticus, is an obligate intracellular symbiont of the amoebae Acanthamoeba sp. (Horn et al., 2001). However, it has a much larger genome and encodes far more proteins than Candidatus Sulcia muelleri, another member of the Bacteroidetes that is an endosymbiont of sharpshooters (McCutcheon and Moran, 2007). In addition, JGI scientists plan to sequence the genome of Candidatus Cardinium hertigii, a symbiont of Encarsia wasps. Comparison of $\mathrm{Ca}$. A. asiaticus with Ca. S. muelleri and $\mathrm{Ca}$. C. hertigii on one hand and to free-living Bacteroidetes on the other should provide further clues to the mechanisms of bacterial adaptation to the endosymbiotic lifestyle.

The second Bacteroidetes member, Polaribacter sp. MED152, is a marine bacterium that was isolated from the surface water of north-western Mediterranean Sea off the Catalan coast (González et al., 2008). In the original GenBank submission, it was listed as a strain of Polaribacter dokdonensis (Yoon et al., 2006), with which it shares $99.6 \%$ similar $16 \mathrm{~S}$ rRNA sequence. However, because of certain phenotypic differences between the two, the authors have chosen to refer to the sequenced organism simply as 'strain MED152'. Together with the previously described Gramella forsetii (Bauer et al., 2006), Polaribacter sp. MED152 represents the marine Bacteroidetes that in certain conditions may comprise up to $20 \%$ of the bacterioplankton. Physiology of these bacteria is still poorly understood, and the authors use the genome of MED152 to offer a very attractive scheme of a 'dual lifestyle' for this organism. Based on the abundance of protease and glycosidase genes, they propose that the normal modus operandi for MED152 includes gliding motility in search for suitable polymers and their subsequent degradation for carbon, nutrients and energy (González et al., 2008). However, once suitable polymeric substrates have been exhausted, MED152 must sustain itself in a nutrient-poor environment. In contrast to G. forsetii, MED152 encodes proteorhodopsin, an
$\mathrm{H}^{+}$-translocating light-dependent ion pump that can use light energy to charge the membrane, generating the proton-motive force. In fact, exposure to light does not stimulate growth of MED152 but appears to stimulate bicarbonate uptake and, conceivably, assimilation of carbon dioxide (González et al., 2008). Accordingly, MED152 encodes a variety of (predicted) light sensors that have not been seen in other members of Bacteroidetes. As noted in the accompanying insightful comment (Kirchman, 2008), the ability of marine bacteria to absorb light and use it to supplement their energy needs has important consequences for the understanding of the global carbon cycle.

In the past 2 months, JGI scientists released six complete genomes of Chlorobi (green sulfur bacteria), five of which, Chlorobaculum parvum, Chlorobium limicola, Chloroherpeton thalassium, Pelodictyon phaeoclathratiforme and Prosthecochloris aestuarii, represent new species and one, Chlorobium phaeobacteroides represents a new strain of the species that had its first sequenced genome 2 years earlier (Table 1). Like other green sulfur bacteria, all these strains are anoxygenic phototrophs that live in strictly anaerobic sulfide-rich environments. They gain energy from photosynthesis, which relies on type I reaction centres and uses sulfide, sulfur and/or thiosulfate as electron acceptors, and fix carbon through the reverse TCA cycle (Overmann and GarciaPichel, 2000; Frigaard and Bryant, 2004). The species differ in their ecological niches and the relative amounts of carotene pigments and bacteriochlorophylls $a, c, d$ and $e$. Green sulfur bacteria play a key role in carbon, nitrogen and sulfur turnover in anoxic freshwater aquatic environments and are a potential source of biomass for biofuels. In addition, Prosthecochloris aestuarii, which forms multilayered biofilms, has been implicated in microbial infection of coral reefs. Comparative analysis of these genomes should clarify many unanswered questions in physiology of these interesting and important organisms.

Natranaerobius thermophilus strain JW/NM-WN-LF is an anaerobic, halophilic alkalithermophile isolated from sediments of a solar-heated, alkaline, hypersaline soda lake at Wadi An Natrun, Egypt (Mesbah et al., 2007). Its optimum growth conditions are $53^{\circ} \mathrm{C}, \mathrm{pH} 9.5$ and between 3.3 and $3.9 \mathrm{M} \mathrm{Na}^{+}$. It cannot grow at $\mathrm{pH}$ lower than 8.3 (or higher than 10.8). This organism belongs to a separate lineage in the class Clostridia and is currently assigned to the separate order Natranaerobiales and family Natranaerobiaceae. A detailed analysis of its genome sequence should clarify the adaptations of $N$. thermophiles to its unique ecological niche but it is already obvious that they include a $\mathrm{Na}^{+}$-dependent $\mathrm{F}_{1} \mathrm{~F}_{\text {o-type }}$ ATP synthase, very similar to the ones in the recently sequenced genomes of Alkaliphilus metalliredigens and Alkaliphilus oremlandii. 
Other organisms with newly sequenced genomes include the chemolithoautotrophic $\alpha$-proteobacterium Oligotropha carboxidovorans (Paul et al., 2008), copperresistant $\beta$-proteobacterium Ralstonia pickettii 12J, plant epiphyte Erwinia tasmaniensis (a non-pathogenic relative of widespread plant pathogens (Kube et al., 2008b), endophytes of the poplar tree Methylobacterium populi (Van Aken et al., 2004) and Stenotrophomonas maltophilia R551-3, tetrachloroethene-dechlorinating $\delta$ proteobacterium Geobacter lovleyi (Sung et al., 2006; Strycharz et al., 2008), new strains of Rhizobium etli, Treponema pallidum and many others (Table 1).

The current list also includes genomes of two mollicutes, Candidatus Phytoplasma mali and Mycoplasma arthritidis. The first one is a phytopathogen infecting apple, cherry, apricot and plum trees. It was isolated in Heidelberg, Germany, from an apple tree displaying symptoms of apple proliferative disease and is the first mycoplasma to have a linear chromosome (Kube et al., 2008a). The second one causes arthritis in rats and mice and is remarkable for carrying a lysogenic bacteriophage (Dybvig et al., 2008).

However, the greatest surprise in the mycoplasma studies came not from genome sequencing labs but from taxonomists. Although mycoplasmas have long been listed in the Division Tenericutes (International Committee on Systematic Bacteriology-Subcommittee on the Taxonomy of Mollicutes, 1995), this clade was usually considered together with Rickettsia and Chlamydia and not treated as an actual taxonomic unit. Instead, Mollicutes were considered a class in the phylum Firmicutes, which was consistent with the available phylogenetic analyses (Falah and Gupta, 1997; Ciccarelli et al., 2006). However, in the recent edition of Bergey's Manual of Systematic Bacteriology, class Mollicutes was excluded from the phylum Firmicutes and moved to the new phylum Tenericutes (Ludwig et al., 2008). While there might have been valid reasons for doing that (for example, many mycoplasma use a non-standard genetic code with UGA codon coding for tryptophan instead of terminating translation), the cited reason for that move was comparative analysis of mycoplasmal sequences by Ludwig and Schleifer (2005), published in a book to which many researchers had no access. Given that the goal of Bergey's Manual is introduction of 'phylogenetic framework' (Ludwig et al., 2008), it seems unfortunate that such important changes are being made without a public discussion or at least a publication in a peer-reviewed journal. After all, massive investments in microbial genome sequencing worldwide have moved bacterial taxonomy from a purely academic sphere into the realm of the biotechnological marketplace, and relatively minor changes in classification could have serious effect on the priorities in future genome sequencing projects.

\section{Acknowledgements}

M.Y.G. is supported by the Intramural Research Program of the NIH, National Library of Medicine. The author's opinions do not reflect the views of NCBI, NLM or the National Institutes of Health.

\section{References}

Bauer, M., Kube, M., Teeling, H., Richter, M., Lombardot, T., Allers, E., et al. (2006) Whole genome analysis of the marine Bacteroidetes 'Gramella forsetii' reveals adaptations to degradation of polymeric organic matter. Environ Microbiol 8: 2201-2213.

Chung, G.T., Yoo, J.S., Oh, H.B., Lee, Y.S., Cha, S.H., Kim, S.J., and Yoo, C.K. (2008) The complete genome sequence of Neisseria gonorrhoeae NCCP11945. $J$ Bacteriol 190: 6035-6036.

Ciccarelli, F.D., Doerks, T., von Mering, C., Creevey, C.J., Snel, B., and Bork, P. (2006) Toward automatic reconstruction of a highly resolved tree of life. Science 311: 12831287.

DeBoy, R.T., Mongodin, E.F., Fouts, D.E., Tailford, L.E., Khouri, H., Emerson, J.B., et al. (2008) Insights into plant cell wall degradation from the genome sequence of the soil bacterium Cellvibrio japonicus. J Bacteriol 190: 54555463.

Dopazo, J., Mendoza, A., Herrero, J., Caldara, F., Humbert, Y., Friedli, L., et al. (2001) Annotated draft genomic sequence from a Streptococcus pneumoniae type $19 \mathrm{~F}$ clinical isolate. Microb Drug Resist 7: 99-125.

Dybvig, K., Zuhua, C., Lao, P., Jordan, D.S., French, C.T., Tu, A.H., and Loraine, A.E. (2008) The genome of Mycoplasma arthritidis. Infect Immun 76: 4000-4008.

Falah, M., and Gupta, R.S. (1997) Phylogenetic analysis of mycoplasmas based on Hsp70 sequences: cloning of the dnaK (hsp70) gene region of Mycoplasma capricolum. Int J Syst Bacteriol 47: 38-45.

Frigaard, N.U., and Bryant, D.A. (2004) Seeing green bacteria in a new light: genomics-enabled studies of the photosynthetic apparatus in green sulfur bacteria and filamentous anoxygenic phototrophic bacteria. Arch Microbiol 182: $265-276$.

González, J.M., Fernández-Gomez, B., Fernàndez-Guerra, A., Gómez-Consarnau, L., Sánchez, O., Coll-Lladó, M., et al. (2008) Genome analysis of the proteorhodopsincontaining marine bacterium Polaribacter sp. MED152 (Flavobacteria). Proc Natl Acad Sci USA 105: 8724-8729.

Horn, M., Harzenetter, M.D., Linner, T., Schmid, E.N., Muller, K.D., Michel, R., and Wagner, M. (2001) Members of the Cytophaga-Flavobacterium-Bacteroides phylum as intracellular bacteria of acanthamoebae: proposal of ' $C a n$ didatus Amoebophilus asiaticus'. Environ Microbiol 3: 440-449.

International Committee on Systematic BacteriologySubcommittee on the Taxonomy of Mollicutes (1995) Revised minimum standards for description of new species of the class Mollicutes (Division Tenericutes). Int J Syst Bacteriol 45: 605-612.

Kirchman, D.L. (2008) New light on an important microbe in the ocean. Proc Natl Acad Sci USA 105: 8487-8488. 
Klasson, L., Walker, T., Sebaihia, M., Sanders, M.J., Quail, M.A., Lord, A., et al. (2008) Genome evolution of Wolbachia Strain wPip from the Culex pipiens group. Mol Biol Evol 25: 1877-1887.

Kocur, M. (1986) Genus Micrococcus Cohn 1972. In Bergey's Manual of Systematic Bacteriology, Vol. 2. Sneath, P.H.A., Mair, N.S., Sharpe, M.E., and Holt, J.G. (eds). Baltimore, MD, USA: The Williams and Wilkins, pp. 1004-1008.

Kube, M., Schneider, B., Kuhl, H., Dandekar, T., Heitmann, K., Migdoll, A.M., et al. (2008a) The linear chromosome of the plant-pathogenic mycoplasma 'Candidatus Phytoplasma mali'. BMC Genomics 9: 306.

Kube, M., Migdoll, A.M., Muller, I., Kuhl, H., Beck, A., Reinhardt, R., and Geider, K. (2008b) The genome of Erwinia tasmaniensis strain Et1/99, a non-pathogenic bacterium in the genus Erwinia. Environ Microbiol 10: 2211-2222.

Lee, J.H., Karamychev, V.N., Kozyavkin, S.A., Mills, D., Pavlov, A.R., Pavlova, N.V., et al. (2008) Comparative genomic analysis of the gut bacterium Bifidobacterium longum reveals loci susceptible to deletion during pure culture growth. BMC Genomics 9: 247.

Lee, J.H., and O'Sullivan, D.J. (2006) Sequence analysis of two cryptic plasmids from Bifidobacterium longum DJO10A and construction of a shuttle cloning vector. Appl Environ Microbiol 72: 527-535.

Ludwig, W., and Schleifer, K.-H. (2005) Molecular phylogeny of bacteria based on comparative sequence analysis of conserved genes. In Microbial Phylogeny and Evolution, Concepts and Controversies. Sapp, J. (ed.). New York, USA: Oxford University Press, pp. 70-98.

Ludwig, W., Schleifer, K.-H., and Whitman, W.B. (2008) Revised road map to the phylum Firmicutes. In Bergey's Manual of Systematic Bacteriology, 2nd edn, Vol, 3, The Firmicutes. De Vos, P., Garrity, G., Jones, D., Krieg, N.R., Ludwig, W., Rainey, F.A., et al. (eds). New York, USA: Springer-Verlag.

Martinez, D., Berka, R.M., Henrissat, B., Saloheimo, M., Arvas, M., Baker, S.E., et al. (2008) Genome sequencing and analysis of the biomass-degrading fungus Trichoderma reesei (syn. Hypocrea jecorina). Nat Biotechnol 26: 553-560.

Matejkova, P., Strouhal, M., Smajs, D., Norris, S.J., Palzkill, T., Petrosino, J.F., et al. (2008) Complete genome sequence of Treponema pallidum ssp. pallidum strain SS14 determined with oligonucleotide arrays. BMC Microbiol 8: 76.

McCutcheon, J.P., and Moran, N.A. (2007) Parallel genomic evolution and metabolic interdependence in an ancient symbiosis. Proc Natl Acad Sci USA 104: 19392-19397.

Mesbah, N.M., Hedrick, D.B., Peacock, A.D., Rohde, M., and Wiegel, J. (2007) Natranaerobius thermophilus gen. nov., sp. nov., a halophilic, alkalithermophilic bacterium from soda lakes of the Wadi An Natrun, Egypt, and proposal of Natranaerobiaceae fam. nov. and Natranaerobiales ord. nov. Int J Syst Evol Microbiol 57: 2507-2512.

Overmann, J., and Garcia-Pichel, F. (2000) The phototrophic way of life. In The Prokaryotes: An Evolving Electronic Resource for the Microbiological Community, 3rd edn, release 32. Dworkin, M. (ed.). New York, USA: SpringerVerlag.
Paul, D., Bridges, S., Burgess, S.C., Dandass, Y., and Lawrence, M.L. (2008) Genome sequence of the chemolithoautotrophic bacterium Oligotropha carboxidovorans OM5T. J Bacteriol 190: 5531-5532.

Pearson, M.M., Sebaihia, M., Churcher, C., Quail, M.A., Seshasayee, A.S., Luscombe, N.M., et al. (2008) Complete genome sequence of uropathogenic Proteus mirabilis, a master of both adherence and motility. J Bacteriol 190: 4027-4037.

Reysenbach, A.-L., Banta, A., Civello, S., Daly, J., Mitchel, K., Lalonde, S., et al. (2005) The Aquificales of Yellowstone National Park. In Geothermal Biology and Geochemistry in Yellowstone National Park. Inskeep, W.P., and McDermott, T.R. (eds). Bozeman, MT, USA: Montana State University, pp. 129-142.

Rosypal, S., and Kocur, M. (1963) The taxonomic significance of the oxidation of carbon compounds by different strains of Micrococcus luteus. Antonie Van Leeuwenhoek 29: 313-318.

Stackebrandt, E., Koch, C., Gvozdiak, O., and Schumann, P. (1995) Taxonomic dissection of the genus Micrococcus: Kocuria gen. nov., Nesterenkonia gen. nov., Kytococcus gen. nov., Dermacoccus gen. nov. and Micrococcus Cohn 1872 gen. emend. Int J Syst Bacteriol 45: 682-692.

Stöhr, R., Waberski, A., Völker, H., Tindall, B.J., and Thomm, M. (2001) Hydrogenothermus marinus gen. nov., sp. nov., a novel thermophilic hydrogen-oxidizing bacterium, recognition of Calderobacterium hydrogenophilum as a member of the genus Hydrogenobacter and proposal of the reclassification of Hydrogenobacter acidophilus as Hydrogenobaculum acidophilum gen. nov., comb. nov., in the phylum 'Hydrogenobacter/Aquifex'. Int J Syst Evol Microbiol 51: 1853-1862.

Strycharz, S.M., Woodard, T.L., Johnson, J.P., Nevin, K.P., Sanford, R.A., Loffler, F.E., and Lovley, D.R. (2008) Graphite electrode as a sole electron donor for reductive dechlorination of tetrachlorethene by Geobacter Iovleyi. Appl Environ Microbiol 74, in press. doi: 10.1128/ AEM.00961-08.

Sung, Y., Fletcher, K.E., Ritalahti, K.M., Apkarian, R.P., Ramos-Hernandez, N., Sanford, R.A., et al. (2006) Geobacter lovleyi sp. nov. strain SZ, a novel metal-reducing and tetrachloroethene-dechlorinating bacterium. Appl Environ Microbiol 72: 2775-2782.

Takarada, H., Sekine, M., Kosugi, H., Matsuo, Y., Fujisawa, T., Omata, S., et al. (2008) Complete genome sequence of the soil actinomycete Kocuria rhizophila. J Bacteriol 190: 4139-4146.

Tang, J.S., and Gillevet, P.M. (2003) Reclassification of ATCC 9341 from Micrococcus luteus to Kocuria rhizophila. Int $J$ Syst Evol Microbiol 53: 995-997.

Van Aken, B., Peres, C.M., Doty, S.L., Yoon, J.M., and Schnoor, J.L. (2004) Methylobacterium populi sp. nov., a novel aerobic, pink-pigmented, facultatively methylotrophic, methane-utilizing bacterium isolated from poplar trees (Populus deltoides $\times$ nigra DN34). Int J Syst Evol Microbiol 54: 1191-1196.

Yoon, J.H., Kang, S.J., and Oh, T.K. (2006) Polaribacter dokdonensis sp. nov., isolated from seawater. Int $J$ Syst Evol Microbiol 56: 1251-1255. 